\title{
REPAIRING HISTORICAL WRONGS AND THE END OF EMPIRE
}

\author{
Daniel Butt, University of Bristol
}

daniel.butt@bristol.ac.uk

Social \& Legal Studies 21,1 (2012).

Please note that this is a pre-publication version of this article. The final version can be found at the Social \& Legal Studies website: http://sls.sagepub.com/content/early/2012/03/23/0964663911435932

It is a truism to say that we live in a world that has been deeply shaped by imperialism. The history of humanity is, in many ways, a story of the attempted and achieved subjugation of one people by another, and it is unsurprising that such interaction has had profound effects on the contemporary world, affecting cultural understandings of community identity; the composition of, and boundaries between, modern day states; and the distribution of resources between different communities. This article addresses the claim that some contemporary states may possess obligations to pay reparations as a result of the lasting effects of a particular form of historic imperialism: colonialism (Ferro 1997: 1-23, Larsen, 2000: 23-40). Claims about the harms and benefits caused by colonialism must make some kind of comparison between the world as it currently is, and a counterfactual state where the injustice which characterised so much of historic interaction between colonisers and the colonised did not occur. Rather than imagining a world a world where there was no such interaction, this article maintains that the appropriate counterfactual is one where relations between different communities were characterized by an absence of domination and exploitation. This means that current day states may possess reparative duties which are much more extensive than is often supposed.

Quite what it means for a form of interaction to be "colonial" is disputed. Osterhammel defines colonialism as "a relationship of domination between an indigenous (or forcibly imported) majority and a minority of foreign invaders" and notes that "the fundamental decisions affecting the lives of the colonized people are made and implemented by the colonial rulers in pursuit of interests that are often defined in a distant metropolis". (1997: 16-17) Such a general description masks the very wide 
range of practices which could be described in such terms: Young writes that colonialism "involved an extraordinary range of different forms and practices carried out with respect to radically different cultures, over many centuries", and lists examples including settler colonies such as British North America, Australia and New Zealand, French Algeria, and Portuguese Brazil; administered territories established without significant settlement for the purposes of economic exploitation, such as American Philippines and Puerto Rico, British India, Dutch East Indies, German Togo or Japanese Taiwan; and maritime enclaves, such as American Guantánamo, British Gibraltar, Hong Kong, Malta, and Singapore (2001: 17). While there is great variety in terms of the experience of colonized peoples, it is nowadays commonplace to maintain that the domination that they suffered at the hands of the colonizing power was unjust. Such claims have a long tradition in both anti-colonial and postcolonial writing, but recent years have seen something approaching a consensus on this point emerging in international political discourse, as evidenced by the condemnation of historic colonialism agreed at the World Conference against Racism, Racial Discrimination, Xenophobia and Related Intolerance in Durban in 2001, Article 13 of which reads:

We recognize that colonialism has led to racism, racial discrimination, xenophobia and related intolerance, and that Africans and people of African descent, and people of Asian descent and indigenous peoples were victims of colonialism and continue to be victims of its consequences. We acknowledge the suffering caused by colonialism and affirm that, wherever and whenever it occurred, it must be condemned and its reoccurrence prevented. We further regret that the effects and persistence of these structures and practices have been among the factors contributing to lasting social and economic inequalities in many parts of the world today. (UN, 2001)

This article is not concerned with the justification, but rather the implications, of this verdict of past wrongdoing. Contemporary movements for reparations can have varied justifications, and seek remedies of differing types. Miller and Kumar list the different forms of "reparations" as including 'money, land, apologies, public memorials and museums, changes in the law, changes in political institutions, enhanced educational opportunities, [and] the introduction of policies designed to educate the general public about the character of past injustices' (2007: v). This article is primarily concerned with the subset of these approaches that involves the compensatory redistribution of resources in 
response to the on-going effects of historical colonialism. Compensation of this type necessarily corresponds to some sort of loss, and calculating such a loss necessarily involves counterfactual comparison between the status quo and a non-existent possible world, which could have come about in the absence of injustice. The key question, then, is that of the lasting wrongful harm caused by colonialism: how should this be characterised and calculated?

It is crucial here to be clear as to the rationale under which claims for reparations stemming from the lasting material effects of colonialism are advanced. Many historic persons had their lives directly impacted by the actions of colonial powers, at times suffering grievous harms and losses. At some times and in some places, colonial domination involved multiple instances of genocide, slavery, rape and sexual enslavement, murder, torture, displacement, and the misappropriation and destruction of property, alongside many other serious moral transgressions. One set of questions concerns what is owed to the direct victims of such actions. In the immediate aftermath of injustice, these are the most pressing questions which corrective justice must answer. As time passes, however, and fewer direct victims remain, a further set of questions gains prominence. Colonialism has had significant effects on many present day communities. Different people would live in different modern day states, with different advantages and disadvantages, had colonial exploitation never taken place. This article argues that insofar as present day communities have benefited, and others have suffered, relative to a counterfactual state where their historic interaction was characterised by an absence of domination and exploitation, they possess contemporary duties of reparation. It maintains that many developed states are guilty of serious wrongdoing in failing to fulfil their reparative obligations, and puts forward principles which suggest a case for a potentially massive redistribution of resources. It may fairly be asked what use such theoretical argumentation, expressed in terms of ideas of morality and justice, is to legal practitioners and political activists at the sharp end of campaigns for the redress of historical wrongdoing. It need not be contended that such redistribution is likely in the short term, nor maintained that pursuing such distributive arguments would be the most effective way of seeking to repair the most pressing harms caused by colonialism. Much contemporary campaigning in relation to colonialism has goals which are not primarily distributive in character. At times, a focus on material 
compensation may not only obscure other more important ends, but prove counter-productive: either by deterring officials from engaging in reconciliatory processes such as apologizing, or by apparently insulting the victims of colonial injustice by belittling or mischaracterizing their suffering. This article is not a critique of existing political campaigns or public rationales for reparations. Its argument is theoretical - it argues that justice requires extensive redistribution in the present day, but it is a further question whether this should form a significant part of the agenda of those involved in seeking the repair of historic wrongs. It is this question which takes centre stage in the extensive contemporary literature on transitional and reparative justice (Teitel, 2000; Thompson, 2002; de Greiff, 2006; Urban Walker, 2006). Instead, my purpose is to determine what modern day distributive rights and obligations are entailed by historic colonial practices. It may be that claims based on such arguments are currently politically infeasible, or that distributive questions are not the most important facing those communities which seek redress for historic wrongdoing. It might also be pointed out, however, that some of the poorest countries in the world are former colonies of some of the richest. For such countries, a conclusion that the developed world is failing to fulfil its distributive duties of rectification in relation to them is of both theoretical but also potentially practical importance. A number of writers have suggested that rectificatory justice has a powerful motivating force: it is easier to make arguments in favour of international redistribution which make reference to past wrongdoing than to appeal to controversial accounts of international distributive justice, such as global egalitarianism (Tan, 2007: 290; Butt, 2009a: 16; see also Pogge, 2002: 132). In cases where symbolic reparation is what is most desired by the descendants of victims, the neglect of distributive concerns may be unproblematic. But there are other contexts where the monetary aspect of reparations is key to the prospects of many current and future people. In such cases, a proper understanding of how past actions affect present day entitlements is vitally important.

\section{HISTORIC INJUSTICE: THE INTERNATIONAL DIMENSION}

Much discussion of historic injustice has traditionally focused on domestic cases, where citizens of a given state, typically belonging to an identifiable group, make a claim against their own 
government stemming from wrongs perpetrated against their ancestors. In the United States, for example, claims have been made by Native Americans in relation to the historic dispossession of indigenous peoples, by African Americans with regard to slavery and its aftermath, and by Japanese Americans in relation to wartime internment (Brooks 1999; Barkan, 2000). The groups involved have often pursued both legal and political strategies - seeking redress through the courts, but also trying to influence public opinion in favour of historic injustice's rectification. Reparative claims have met with mixed judicial results - whilst there have been notable successes, other claims have largely been rebuffed or ignored. Recent years have seen growing interest in a different set of cases, where the perpetrators and victims of historic injustice were members of different modern day states. Legal strategies are rarely viable in such cases, owing to the fact that international legal prohibitions on various forms of unjust international interaction have a relatively recent genesis and generally do not have retrospective force (Reshetov 1990, Butt 2009b). Such cases accordingly have a political character - the aim is to pressurise or persuade the modern day polity in question to apologise for and/or pay reparations in response to the actions of its historic forebear. Two sets of claims have achieved particular prominence: one arising from the actions of the Axis powers in the Second World War, and one relating to the wrongs of the colonial period, and of European colonialism in particular, including the slave trade. This article focuses on this second set of claims. To what extent do modern day polities owe rectificatory duties to others as a result of actions originating in their imperial past? Specifically, how does the fact that the historic interaction between two polities was colonial in character affect conventional arguments relating to the rectification of historical injustice?

To answer this question, it is necessary to consider the relation between distributive and rectificatory, or corrective, justice. Any account of rectificatory justice, which seeks to reallocate or redistribute contemporary resource holdings in response to historic injustice, must engage with ideas of distributive justice, which seeks to determine the fair distribution of benefits and burdens in a given society. If we are, for example, to return misappropriated possessions to their rightful owners, we 
need some reason to hold that the owners are indeed in some sense entitled to the property in question, that their title at least legitimate. As Jules Coleman writes:

In order for a scheme of rights to warrant protection under corrective justice... they must be sufficiently defensible in justice to warrant being sustained against individual infringements. Entitlements that fail to have this minimal property are not real rights in the sense that their infringements cannot give rise to a moral reason for acting . (1992: 352)

In broad terms, efforts to rectify the distributive effects of historic injustice have most relevance in contexts where distributive justice has a significant backward-looking context - where the actions of previous generations make a difference to the entitlements of persons in the present. If history is not of great importance to the question of who owns what in the present day, then there will be little reason to suppose that past wrongdoing will cast a shadow over contemporary property holdings. So if, for example, one advocates highly redistributive, egalitarian principles of distributive justice, which (say) allocate an equal share of resources to each individual at the start of each new generation, and prohibit the transfer of advantage from one generation to another by mechanisms such as inheritance, then one's concern for backward-looking rectificatory justice will be very limited. Although there may still be good reasons to care about the past, if, for example, it affects modern day ideas of group identity, arguments in favour of reparations will typically be grounded in the symbolic effects of making amends for the past - the distributive injustice of the past wrongdoing will have been, to use Jeremy Waldron's terminology, superseded. (Waldron: 1992) By contrast, if one thinks that it can be legitimate for property to be transferred from one generation to the next, so that one's social background makes a significant difference to how well one's life goes, then the provenance of one's advantages becomes much more significant - and the case for rectification, in contexts where these advantages have come about unjustly at the expense of others, much stronger. (Nozick, 1974: 231) 
The relevance of historic injustice to present day distributions, then, turns on the backward- or forward-looking character of one's account of distributive justice. It is not unusual to oppose the rectification of historic wrongs on the basis of a forward-looking account of distributive justice rather than seeking to restore potentially suspect historic distributions, it might be asked, should we not look forward and seek to bring about just distributions of benefits and burdens? (Waldron, 1992; Vernon, 2003; Wenar, 2006) It is here that the distinction between domestic and international injustice becomes significant. Many writers and real world actors support quite different principles of distributive justice in domestic and in international contexts, advocating broadly egalitarian principles when it comes to relations with fellow citizens, but much less redistributive principles in relation to persons living in other political communities (Rawls, 1999; for discussion, see Caney, 2002). A range of reasons can be given for this difference in approach - rooted in, for example, the shared nationality of members of particular nation states (Miller, 2007), or the fact that citizens of specific states are all subject to the same coercive laws which do not apply in the same way to those living in other countries (Blake, 2002; Nagel, 2005) - but the fact remains that for such writers, there is a much more compelling rationale for redistribution within, rather than across, state boundaries. The result is there is widespread endorsement of forward-looking principles of distributive justice, stressing egalitarian principles such as equality of opportunity, at a national level, but that international distributive justice is generally portrayed in primarily backward-looking fashion, with an emphasis on collective responsibility and self-determination. If one holds that the state in which one lives makes a difference when it comes to who should have what, then one necessarily needs a distinct account of international rectificatory justice - and this account will have to take seriously the question of how contemporary resource holdings have come about. This opens the door to reflection on the distributive legacy of historical colonialism.

The observation, however, that present day advantages and disadvantages were rooted in historical injustice does not in itself establish the existence of present day reparative obligations. The problem here concerns the effects of the passage of time. It is one thing to maintain that a given political community possesses reparative obligations immediately following an act of international 
injustice. Such a claim is itself controversial in terms of its willingness to hold peoples collectively responsible for the actions of their leaders, but the principle is widely accepted, particularly if the community in question has at least some kind of democratic character. (Glenn Gray, 1998: 198-9; Miller, 2004: 262; Butt, 2009a: 178-183; Pasternak, 2011) This need not represent a claim that the people as a whole are morally responsible for the commission of injustice. The point is more simply that they face an obligation to put right the actions of their leaders. Things are more problematic when we consider events which took place a considerable amount of time in the past. Why should present day communities, not alive at the time of the original injustice, be obliged to pay for the sins of their ancestors? A range of different answers have been put forward in response to this question. Some suggest communitarian approaches which focus on the fact that individuals are members of communities which persist through time in a way that their individual members do not, and suggest that membership of a given community unavoidably comes with pre-existing commitments (for discussion, see Fabre, 2007: 150-55), or stress the on-going responsibilities of political institutions, which similarly can have an on-going identity across different time periods, in analogous fashion to a corporation (Tan, 2007). Others suggest mechanisms by which individual members of one generation can come to have remedial responsibility to right another's wrongs (Thompson, 2002; Abdel Nour, 2003; Butt, 2006). Perhaps the most straightforward pro-reparations argument, however, is based in the idea of unjust enrichment. It holds that those who benefit from the wrongdoing of others can possess reparative obligations to the victims of injustice, even though they are not responsible for the original wrongdoing. Such an approach is controversial in its non-voluntarist methodology (see Fullinwider, 2002; Anwander, 2005), but some, at least, are willing to accept that the beneficiaries of injustice can have such obligations (Thomson, 1986; Butt, 2007). The claim is often made in environmental contexts in support of the 'beneficiary pays' principle, which holds that those who benefit involuntarily from certain forms of harmful pollution can justifiably be held responsible for its costs (Gosseries, 2004). Strikingly, the 'benefit' rationale was explicitly invoked by the Group of 21 in their draft declaration for the 2001 UN World 
Conference, which argued that reparations to victims of colonialism should be contributed to by 'States, companies and individuals who benefited materially from these practices' (Tan, 2007: 280). Suppose it is granted that it is possible for rectificatory duties to arise by these sorts of mechanisms, such that we can construct a paradigm case of historic international injustice in need of present day rectification, where we assign reparative duties to those harmed by historic wrongdoing to the present day community or communities who have benefited from the historic wrongdoing (who often will be the direct descendants of the transgressors). Let us accept that in this type of case there is a moral basis for reparations as a result of (a) the generally backward-looking background account of distributive justice, (b) the presence of on-going harm caused by historic wrongdoing, and (c) the existence of a class of persons who have benefited from the harm in question. How does the shift to the colonial context complicate things?

\section{$\underline{\text { THE COLONIAL DIMENSION }}$}

In keeping with the paradigm case outlined above, many claims arising from historical colonialism are international in character - they are made by members of one present day state against another. Even if there are multiple linkages between the communities in the present day, such as the existence of significant migrant communities in either or both states, close trading relationships, or formal structures such as the British Commonwealth, there is no single overarching authority with the power to redistribute resources from members of one state to members of another. In this regard they are members of separate, backward-looking schemes of distribution - even if this may not have been the case in the past (Ypi, Goodin, and Barry, 2009). Clearly, the precise sovereign entities which exist in the present day may well be different from those which existed historically. There are currently 192 states who are members of the United Nations. By contrast, 51 states were represented at the first UN General Assembly in 1946. For a range of reasons, notably including processes of decolonization, the set of states which currently exists is very different from that of fifty or a hundred years ago. This certainly complicates the legal case for reparations, but is less problematic from the perspective of the 
'beneficiary pays' model, which puts aside issues of the continuous identity of political entities, and merely asks who has benefited, and who has suffered, as a result of historic injustice.

It is this issue, of the nature of the purported modern day harm caused by colonialism, which complicates the case for reparations in postcolonial contexts. The extent to which colonialism has indeed had lasting harmful consequences is the subject of heated debate amongst historians in many different countries. Does historic colonialism continue to cause harm to persons living in the present and if so, how much? This question is typically framed in terms of the net effects of colonialism, and asks whether particular former colonies might now be better off than they would have been had colonialism not taken place - or, at least, if there might not be some sense in which they have benefited. This need not serve as a defence of colonialism per se; the claim may simply be that present day members of the former colony are not worse off as a result of the historic treatment of their ancestors than they would be had their ancestors not been treated in the way they were. This issue is a recurrent theme of historical debate relating, for example, to the British Empire. It once again came to the fore in April 2011, when the British Prime Minister David Cameron addressed a group of school children in Pakistan, and appeared to question the Empire's legacy, stating: 'As with so many of the problems of the world, we are responsible for their creation in the first place.' A familiar debate unfolded in the British media. The BBC opposed the views of two historians, Nick Lloyd and Andrew Thompson. Lloyd argued that Cameron's comments revealed 'a disappointing lack of historical judgment', describing the British Empire in India as 'the greatest experiment in paternalistic imperial government in history', and maintaining that British rule left a still-persisting legacy of 'a number of priceless assets', including the English language, governmental structures, and logistical infrastructure, concluding that 'far from damaging India, British imperial rule gave it a head start'. While Lloyd held that 'the empire gave its colonies real, tangible benefits', Thompson instead focused on 'the inheritance of colonial violence' in places such as Kenya, Palestine, Malaysia, Zimbabwe, and Northern Ireland, and questioned whether 'the violence that characterised...counterinsurgency operations during decolonisation then set the scene for the way in which independent, 
post-colonial African and Asian governments dealt with political dissent from their own peoples', concluding that, "the imperial past is far from being dead. On the contrary it is actually very much part of contemporary politics' (BBC News, 2011). Such, debates, of course, are not exclusive to Britain. One finds, for example, similar discussions in historical writing on the character of French colonialism, reflected in the French government's legislation of 2005 requiring that colonial history be taught in a "positive" manner in French schools (Tyre, 2008: 152), which held that "School courses should recognise in particular the positive role of the French presence overseas, notably in north Africa" (Henley, 2005); in debates over the lasting effects of Japanese colonialism in areas including China and Korea (Sand, 1999); in the "history wars" in Australia concerning the effects of British colonialism on Australian Aborigines and Torres Strait Islanders,(Macintrye and Clark, 2004) and so on.

One might also look at the extensive literature in social science which seeks to use comparative analysis to quantify the differential effects of different forms of colonisation. Feyrer and Sacerdote, for example, use this form of analysis to study the effects of colonialism on a database of islands throughout the Atlantic, Pacific and Indian Oceans. They identify "a robust positive relationship between the years of European colonialism and current levels of income" (which, they suggest, is at least partly causal in nature) whilst also differentiating between the effects of different colonial powers and eras. Thus, they claim that "there is a discernable pecking order amongst the colonizers. Years under US and Dutch colonial rule are significantly better than years under the Spanish and Portuguese", and that "later years of colonialism are associated with a much larger increase in modern GDP than years before 1700" (2009: 256).

It might be thought that such questions map directly onto the reparations debate. The suggestion is that compensation is only due if it can be shown that members of former colonies are still suffering a net loss as a result of the experiences of their ancestors. Even if it is accepted that there is a net loss, it still may be maintained that the positive effects of colonialism should be taken 
into account when calculating what is owed - that they should, as it were, offset the bill for reparations. This issue can be differentiated from the debate over apologies, where it can be claimed that there should be apologies for each and every moral transgression, regardless of the net overall impact of colonialism as a whole. But as the benefit model does not seek to hold modern day parties responsible for historic injustice, the 'net loss' approach appears to be appropriate. The historical debate over the extent of this loss, of course, is deeply contentious. In a British context, while some follow Lloyd in pointing to purported institutional and cultural benefits to former colonies (Ferguson, 2002), others have argued that such a perspective massively underestimates both the historical damage wrought by the colonialists and its long-lasting effects (Newsinger, 2006). In seeking to conduct a "moral audit" of the British Empire, Piers Brendon first observes that "The moral balance sheet of the British Empire is a chaotic mixture of black and red", before arguing that "All balance sheets require interpretation; but it seems clear that, even according to its own lights, the British Empire was in grave moral deficit", pointing not only to the historic "catalogue of gross imperial wrongdoing" but also the fact that "much of the imperial legacy was failed states and internecine strife" (Brendon, 2007). The fundamental rationale of this type of assessment - that the current state of the postcolonial communities is being compared with some kind of world where colonialism did not take place - is rarely scrutinized. Although there is huge disagreement as to the relative weight of benefit and loss, it is commonplace even amongst advocates of reparations to find acknowledgements that colonialism had some positive aspects: witness Tan's statement that, 'The history of colonialism is, of course, a highly complex one. There is no denying that colonized people have also benefited in different ways from their encounter with the colonizing power' (2007: 281). Such an acknowledgement opens up a vulnerability in the pro-reparations argument, as it seemingly makes the case for reparations dependent on the resolution to the historical debate on net loss. It is this move which should be resisted.

The question of what it means to benefit or suffer as a result of wrongdoing is key here. In everyday discourse relating to compensation, reference is sometimes made to the idea of the status quo ante. 
One compensates someone for something, it is supposed, by restoring the state of affairs that obtained prior to the act of injustice. This is problematic, since it is not hard to think of cases where trying to turn back the clock in this way leaves the victim worse off than she would have been had the act of injustice not taken place. Thus the point of compensation is seen as being to redress the difference between a victim's current state and the state she would be in had the act of injustice not taken place. As Nickel writes, "Compensatory justice requires that counterbalancing benefits be provided to those individuals who have been wrongly injured which will serve to bring them up to the level of wealth and welfare that they would now have if they had not been disadvantaged" (Nickel, 1977: 327) The problem here is that, unlike in the status quo ante case, there is no fact of the matter as to how a victim would have fared in the absence of injustice, and so reference has to be made to some possible state of affairs that might have come about in the absence of the unjust action. How should this counterfactual be calculated, given the countless number of ways in which history might have unfolded? The standard response appeals to the most likely outcome - what would most probably have occurred had the injustice not taken place. We measure the difference between someone's current state and the state she would probably be in had injustice never occurred and hold the perpetrator responsible for making up the difference between the real world and this possible world.

In many cases, this is indeed the right kind of comparison to employ. However, in some situations, this leads to intuitively unacceptable consequences, and so calculations of just compensation instead make use of a quite different mode of counterfactual comparison. Feinberg employs the example of a businessman who is injured as a result of his driver's negligently reckless driving, but as a result misses a flight which goes on to crash (Feinberg, 1992: 8). Rather than asking what would have been the most likely outcome had the driver not acted wrongly, he claims we should consider a 'doubly counterfactual' alternative in such cases, where the driver acts properly and the plane does not crash (Feinberg, 1992: 11). It might be highly unlikely that such an outcome would have actually come about had the driver acted properly, but nonetheless compensatory justice requires us to suspend our disbelief and use this possible world as the basis for assessing the harm which the wrongdoing has caused. Similarly, a mugger cannot escape his duty to compensate his victim by 
observing, however accurately, that had he not attacked his victim, another, more brutal mugger would have done so - instead, we construct a doubly counterfactual case where there was no mugging at all. (Feinberg, 1992: 8) The common element to both examples is the idea that thinking about the most likely outcome in the absence of the intervention of the wrongdoer does not seem to be the right way to isolate the harm done by the wrongdoing in question. Though it is likely in such cases that the net interest of the victim is not lower than it would have been had there been no interaction between wrongdoer and victim, we nonetheless want to maintain that the victim has been not just been wronged, but wrongfully harmed, and so is entitled to compensation.

The construction of the doubly counterfactual formulation is particularly appropriate when it comes to the consideration of cases of exploitation. The specification of what constitutes exploitation is controversial philosophically, but different accounts generally reflect the idea that to exploit someone is, in some sense, to take unfair advantage of them (Goodin 1987: 166; Wertheimer 1996: 16; Logar 2010: 333). Exploitation typically arises in cases where one party takes wrongful advantage of another in a context of unequal power relations, and such unequal power relations were evidently the norm in colonial contexts defined by relations of domination and subjugation. Indeed, to a large extent, the desire to take wrongful advantage provided the rationale for colonialism itself: as Young writes, "Colonisation was not primarily concerned with transposing cultural values. They came as a by-product of its real objectives of trade, economic exploitation and settlement." (2001: 24) In cases of exploitation which involved labour and material production - literally, the blood, sweat and tears of the victims of injustice - to invoke the most likely outcome in the absence of interaction badly mischaracterises the appropriate counterfactual. Instead, a counterfactual should be employed which includes this labour, but imagines a way in which it could have come about through non-dominated cooperation - however unlikely this would have been in practice. As argued above, historic colonialism took many different forms, and we can delineate a wide variety of different forms of interaction between the colonisers and the colonised. But insofar as these are instances of colonial interaction, they take place, by definition, within a context of domination. Even if the historic interaction appears to have been consensual, if one party stood in an unequal power relation to another 
as a result of unjust colonial expansion, the potential for the unjust taking of advantage, and thus, for exploitation, was there. Insofar as this led to one side gaining more, and the other less, than they should have done had the relationship been fair and non-dominated, there is a case for reparation and this stands regardless of the likely fate of the exploited party in a possible world where there was no interaction between coloniser and the colonised.

One way to think about this is to consider forms of contemporary international interaction which some hold to be exploitative, such as instances of trade between the developed and developing world in commodities such as coffee. Take the claim of fair trade advocates that certain seemingly consensual trade practices are unjust since they do not pay workers a fair price for their labour. Such a view need not depend upon a claim that the workers in question are actually worse off given the practice than they likely would be if there were no interaction with the exploiting corporation. The fair trade advocate can maintain that the transaction is unfair since the worker is underpaid relevant to a counterfactual whereby the worker is paid what is deemed a fair wage. It may well be that such an advocate might accept that it is likely that the workers would actually be worse off had they never been contracted: this counterfactual, however, fails to take into account the production which has been generated by their exploitation but which would not exist in the most probable possible world where exploitation is absent. If we affirm that exploitation is unjust and gives rise to rectificatory obligations, the appropriate counterfactual is not one whereby the exploitee had no interaction with the exploiter at all, but rather one whereby the exploitee was a non-exploited partner in the collaborative enterprise, and so was paid a fair wage. The exploitative character of the fair trade case is controversial, since it rests upon the claim that exchanges whereby one party accepts a price which is less than some externally derived fair benchmark price are exploitative, even in the absence of any kind of coercion or rights violation (see Wertheimer, 1996: 10-12). The wrongful character of colonial exploitation, however, is significantly more straightforward insofar as the difference in power relations emerges as a result of colonial domination. If we hold that colonial domination was unjust, then it follows that taking advantage of the unequal power relations which resulted was wrongfully exploitative. The morally relevant counterfactual in such cases is one whereby this production 
occurred in non-dominated circumstances - however unlikely it is that this would actually have taken place in practice.

A striking example of the misapplication of counterfactual reasoning in relation to colonialism is found in the recent work of the historian Niall Ferguson (2002). Ferguson explicitly links his assessment of the question of whether the British Empire was a 'Good Thing' or a 'Bad Thing' to the reparations debate. Ferguson does not explain the meta-ethical character of his assessment, but seems to favour a crude form of utilitarianism, writing 'Prima facie...there seems a plausible case that the Empire enhanced global welfare - in other words, was a Good Thing', and noting that the arguments against imperialism can be 'summarized... under two headings': 'those that stress the negative consequences for the colonized; and those that stress the negative consequences for the colonizers' (2002: xx). Despite observing that 'the imagination reels from the counterfactual of a world without the British Empire', he nonetheless proposes a balance sheet which lists both the good and the bad of the Empire, strongly suggesting that the net balance was positive. He first invokes a status quo ante argument:

To imagine the world without the Empire would be to expunge from the map the elegant boulevards of Williamsburg and old Philadelphia; to sweep into the sea the squat battlements of Port Royal, Jamaica; to return to the bush the glorious skyline of Sydney; to level the steamy seaside slum that is Freetown, Sierra Leone; to fill in the Big Hole at Kimberley; to demolish the mission at Kuruman; to send the town of Livingstone hurtling over the Victoria Falls. (Ferguson, 2002: xxi)

...before invoking a counterfactual grounded in probability:

It is of course tempting to argue that it would all have happened anyway, albeit with different names.... Yet there is reason to doubt that the world would have been the same or even similar in the absence of the Empire.... Would other empires have produced the same effects? It seems doubtful. (Ferguson, 2002: xxi-ii) 
There is much here which might be disputed, as the work of anti-apologists such as Newsinger makes clear. But crucially, the reparations advocate need not be drawn into this debate as to what would likely have happened in the absence of Britain's imperial misadventures. To oppose reparations claims on the basis of this kind of reasoning is straightforwardly mistaken. The appropriate counterfactual here is not that which would most probably have come about in the absence of any interaction between colonizers and their colonies, nor that whereby the colonies are subject to even more brutal treatment at the hands of a different power. Instead, we should imagine a possible world however unlikely - where there was productive interchange between the different political communities, but where this was consensual and non-exploitative. Ferguson concludes his Preface by posing the following rhetorical question:

For better, for worse - fair and foul - the world we know today is in large measure the product of Britain's age of Empire. The question is not whether British imperialism was without a blemish. It was not. The question is whether there could have been a less bloody path to modernity. Perhaps in theory there could have been. But in practice? (2002: xxv)

It is sufficient for those who argue in favour of reparations for colonialism that the less bloody path is there in theory. However unlikely it is to imagine that various forms of development would have emerged in the absence of egregious wrongdoing, this is nonetheless the appropriate counterfactual to consider in assessing present day levels of benefit and disadvantage stemming from the colonial past. There are, of course, many such possible worlds, and a full account of rectificatory justice will have to come to a conclusion as to which is the most appropriate in each given case. Whichever possible world is deemed most appropriate, however, it will be one which imagines fair cooperation between colonizer and colonised in a mutually beneficial context of non-domination. Writing in 1955, Aimé Césaire characterized the African colonial experience as follows:

the great historical tragedy of Africa has been not so much that it was too late in making contact with the rest of the world, as the manner in which that contact was brought about; that Europe began to "propagate" at a time when it had fallen into the hands of the most unscrupulous financiers and captains of industry; that it was our 
misfortune to encounter that particular Europe on our path, and that Europe is responsible before the human community for the highest heap of corpses in human history. (Césaire, in Olaniyan, 2000: 269)

From the perspective of modern day compensatory justice, it is not the fact of contact, but precisely the tragic and morally horrific manner in which contact was brought about which stands in need of redress.

\section{CONCLUSION}

This article has argued that modern day communities should ask themselves whether they are better off, and others are worse off, than they would be had the historic productive interaction between them been consensual and cooperative in character. A situation where they are advantaged, and others disadvantaged, relative to this counterfactual is unjust, and gives rise to rectificatory obligations. How such obligations should be met is a difficult question. One possibility, of course, is simply to suggest a straightforward transfer of resources, such as a cash payment, but there are a range of other alternatives, including debt relief, the granting of advantageous access to markets, development assistance, forms of exemption from free trade agreements, and so on (Tan, 2007: 28081). The disadvantage in question is unlikely to be easily resolved by a one-off payment: instead, what is indicated is the need for an on-going commitment on the part of the advantaged party to correct the distributive distortion caused by both the initial wrongdoing and the subsequent failure to fulfil rectificatory obligations. None of this is likely to happen overnight. Most former colonial powers have not even begun to come to terms, in any sort of meaningful way, with their imperial pasts - frequently refusing to compensate even surviving victims of terrible and obvious wrongdoing, such as torture at the hands of the British in the Kenyan Emergency, or sexual enslavement by the Japanese military during World War II. But a key conclusion of this article is that the rectificatory obligations of such countries are not limited to these surviving victims. The on-going failure to do what can be done to repair such terrible injustices is a grievous wrong which, following the death of the original victims, can never be righted. But this failure to fulfil rectificatory duties does not get 
former colonial powers off the compensatory hook as time passes. Recent literature on compensatory justice has stressed the extent to which the failure to rectify injustice itself counts as an act of injustice (Boxill, 2003; Sher, 2005; Butt, 2006). The passage of time does mean that a particular set of reparative obligations - to the direct victims of injustice - lapses. But this need not lead to the conclusion that all that is needed can be found in the non-distributive domain of apology, education and symbolic action. For as long as we continue to live in a world where the distribution of resources is literally of vital importance, the failure of colonial powers to fulfil their reparative duties to the peoples they have wronged is a continuing injustice, which cries out for rectification.

\section{REFERENCES}

Abdel-Nour, Farid (2003) ‘National Responsibility’, Political Theory 31: 693-719.

Anwander, Norbert (2005) 'Contributing and Benefiting: Two Grounds for Duties to the Victims of Injustice', Ethics and International Affairs 19: 39-45.

Barkan, Elazar (2000) The Guilt of Nations: Restitution and Negotiating Historic Injustices. New York: Norton.

BBC News (2011) 'Is Britain to Blame for Many of the World's Problems?', 7 April 2011 [online] available at http://www.bbc.co.uk/news/magazine-12992540 [accessed 24 November 2011].

Blake, Michael (2002) Distributive justice, state coercion, and autonomy', Philosophy and Public Affairs 30: 257-96.

Boxill, Bernard R. (2003) 'A Lockean Argument for Black Reparations', The Journal of Ethics 7: 6391.

Brendon, Piers (2007) 'A Moral Audit of the British Empire’ History Today 57: 44-7.

Brooks, Roy L. (1999) When Sorry Isn't Enough: The Controversy over Apologies for Human Injustice. New York: New York University Press.

Butt, Daniel (2006) 'Nations, Overlapping Generations and Historic Injustice', American Philosophical Quarterly 43: 357-67.

- (2007) 'On Benefiting from Injustice’, Canadian Journal of Philosophy 37: 129-52. 
- (2009a) Rectifying International Injustice: Principles of Compensation and Restitution between Nations. Oxford: Oxford University Press.

- (2009b) 'Victors' Justice? Historic Injustice and the Legitimacy of International Law' pp.

163-185 in Lukas H. Meyer (ed.), Legitimacy, Justice and Public International Law.

Cambridge: Cambridge University Press.

Caney, Simon (2002) 'Survey Article: Cosmopolitanism and the Law of Peoples', The Journal of Political Philosophy 10: 95-123.

Coleman, Jules L. (1992) Risks and Wrongs. Cambridge: Cambridge University Press.

De Greiff, Pablo (2006) 'Justice and Reparations’ pp. 451-77 in de Greiff (ed.) The Handbook of Reparations. New York: Oxford University Press.

Fabre, Cécile (2007) Justice in a Changing World. Cambridge: Polity.

Feinberg, Joel (1992) Freedom and Fulfilment: Philosophical Essays. Princeton: Chichester.

Ferguson, Niall (2002) Empire: The Rise and Demise of the British World Order and the Lessons for Global Power. London: Allen Lane.

Ferro, Marc (1997) Colonization: A Global History trans. K.D. Prithipaul. London: Routledge.

Feyrer, James and Sacerdote, Bruce (2009) “Colonialism and Modern Income: Islands as Natural Experiments" The Review of Economics and Statistics 91: 245-26.

Fullinwider, Robert (2002) 'Preferential Hiring and Compensation', pp. 68-78 in Steven M. Cahn (ed), The Affirmative Action Debate. New York: Routledge.

Glenn Gray, J. (1998) The Warriors: Reflections on Men in Battle. Lincoln, Neb.: University of Nebraska Press

Goodin, R. (1987) 'Exploiting a situation and exploiting a person' in A. Reeve (ed.), Modern theories of exploitation. London: Sage, 166-200

Gosseries, Axel (2004) 'Historical Emissions and Free-riding', Ethical Perspectives 11: 38-62.

Henley, John (2005) 'French angry at law to teach glory of colonialism' The Guardian 15/4/2005 [online] available at 
http://www.guardian.co.uk/world/2005/apr/15/highereducation.artsandhumanities [accessed 24 November 2011].

Larsen, Neil, (2000) “Imperialism, Colonialism, Postcolonialism”, pp. 23-52 in Henry Schwarz and Sangeeta Ray (eds.) A Companion to Postcolonial Studies. Blackwell, Oxford.

Logar, Tea (2010), 'Exploitation as Wrongful Use: Beyond Taking Advantage of Vulnerabilities', Acta Analytica 25, 329-346.

Macintyre, Stuart and Clark, Anna (2004) The History Wars. Melbourne: Melbourne University Press. Miller, David (2004) 'Holding nations responsible', Ethics 114, 240-68.

- (2007) National Responsibility and Global Justice. Oxford: Oxford University Press.

Miller, Jon and Rahul Kumar (eds) (2007) Reparations: Interdisciplinary Inquiries. Oxford: Oxford University Press.

Nagel, Thomas (2005) 'The Problem of Global Justice', Philosophy and Public Affairs 33: 113-47.

Newsinger, John (2006) The Blood Never Dried: A People's History of the British Empire. London: Bookmarks.

Nickel, James (1977) 'Preferential policies in hiring and admissions: a jurisprudential approach', pp. 324-47 in Barry Gross (ed.), Reverse Discrimination. Buffalo: Prometheus.

Nozick, Robert (1974) Anarchy, State, and Utopia New York: Basic Books

Olaniyan, Tejumola (2000) “Africa: Varied Colonial Legacies”, pp. 269-281 in Henry Schwarz and Sangeeta Ray (eds.) A Companion to Postcolonial Studies. Blackwell, Oxford.

Osterhammel, Jürgen Colonialism: A Theoretical Overview, trans. Shelley L. Frisch. Princeton, NJ: Marcus Wiener.

Pasternak, Avia (2011) 'The Collective Responsibility of Democratic Publics' Canadian Journal of Philosophy 41: 99-124.

Pogge, Thomas (2002) World Poverty and Human Rights. Cambridge: Polity. Rawls, John (1999) The Law of Peoples. Cambridge, MA: Harvard University Press. 
Reshetov, Iu A.(1990) ‘The Temporal Operation of Norms on Criminal Responsibility’, pp. 111-17 in

G. Ginsburg and V.N. Kudriavtsev (eds.), The Nuremberg Trial and International Law (Dordecht:

Martinus Nijhoff).

Sand, Jordan (1999) 'Historians and Public Memory in Japan: The "Comfort Women" Controversy: Introduction', History \& Memory 11: 117-126

Sher, George (2005) 'Transgenerational Compensation', Philosophy and Public Affairs 33: 181-200.

Tan, Kok-Chor (2007) ‘Colonialism, Reparations, and Global Justice', pp. 280-306 in Jon Miller and Rahul Kumar (eds), Reparations: Interdisciplinary Inquiries. Oxford: Oxford University Press.

Teitel, Ruti G. (2002) Transitional Justice. New York: Oxford University Press.

Thompson, Janna (2002) Taking Responsibility for the Past: Reparations and Historical Injustice. Cambridge: Polity.

Thomson, Judith Jarvis (1986) Rights, Restitution and Risk: Essays in Moral Theory. London: Harvard University Press.

Tyre, Stephen (2008) ‘France and its Colonies: Historiography’, pp. 152-7 in Prem Poddar, Rajeev Shridhar Patke, Lars Jensen (eds.) A Historical Companion to Postcolonial Literatures: Continental Europe and Its Empires. Edinburgh: Edinburgh University Press.

United Nations (2001) Declaration of the World Conference against Racism, Racial Discrimination, Xenophobia and Related Intolerance, available at http://www.un.org/WCAR/durban.pdf [accessed 24 November 2011].

Urban Walker, Margaret (2006) 'Restorative Justice and Reparations’, Journal of Social Philosophy 37: $377-95$.

Vernon, Richard (2003) 'Against Restitution, Political Studies 51: 542-57

Waldron, Jeremy (1992) ‘Superseding Historic Injustice’, Ethics 103: 4-28.

Wenar, Leif (2006) 'Reparations for the Future' Journal of Social Philosophy 37: 396-405

Wertheimer, A. (1996) Exploitation. Princeton: Princeton University Press.

Young, Robert (2001) Postcolonialism: An Historical Introduction. Blackwell: Oxford 
Ypi, L., R. Goodin, and C. Barry (2009) 'Associative Duties, Global Justice, and the Colonies’ Philosophy \& Public Affairs 37: 103-35. 